\title{
KARAKTERISTIK SIKAP MENTAL WIRAUSAHA MAHASISWA DALAM BIDANG OTOMOTIF
}

\author{
Agil N. Maulida ${ }^{1}$, Inu H. Kusumah ${ }^{2}$, Tatang Permana ${ }^{3}$ \\ Departemen Pendidikan Teknik Mesin \\ Universitas Pendidikan Indonesia \\ J1. Dr. Setiabudhi No. 207 Bandung 40154 \\ agil.oto2008@gmail.com
}

\begin{abstract}
ABSTRAK
Tujuan dari penelitian ini adalah untuk memperoleh gambaran tentang karakteristik sikap mental wirausaha mahasiswa DPTM FPTK UPI Bandung dalam bidang otomotif. Metode penelitian ini yaitu penelitian deskriptif dengan pendekatan kuantitatif. Hasil penelitian diperoleh mahasiswa yang memiliki sikap mental wirausaha sangat rendah dan sangat tinggi jumlahnya paling sedikit. Mahasiswa yang memiliki sikap mental wirausaha tinggi memiliki jumlah paling banyak. Secara umum sikap mental wirausaha dalam bidang otomotif di kalangan mahasiswa prodi otomotif DPTM FPTK UPI Bandung ada pada kategori tinggi. Kesimpulan penelitian ini yaitu ada kecenderungan mahasiswa yang memiliki sikap mental wirausaha yang tinggi dapat berpotensi menjadi seorang wirausahawan.
\end{abstract}

Kata kunci: karakteristik, sikap mental, wirausaha, mahasiswa, otomotif

\section{PENDAHULUAN}

Pada saat ini ada lebih 600.000 lulusan perguruan tinggi di Indonesia menganggur atau tidak bekerja. Sebagian besar mereka atau 420.000 orang dari jenjang pendidikan S1 dan sisanya diploma. Pengangguran terbuka lulusan universitas di Indonesia berjumlah 398.298 orang atau 4,31\% dari total pengangguran terbuka yakni sebanyak 7.147.069 orang (BPS, 2014). Hal inilah yang menjadi acuan bahwa pentingnya bagi mahasiswa menjadi wirausaha, supaya bisa lebih serius memperdalam ilmu kewirausahaan dan sikap mental dirinya untuk menjadi wirausaha.

Mengingat pentingnya kewirausahaan bagi kesejahteraan ekonomi dan sosial mahasiswa tertentu, perlu adanya penelitian untuk mengidentifikasi sikap mental mahasiswa DPTM FPTK UPI Bandung khususnya mahasiswa prodi otomotif untuk menjadi wirausaha. Sikap mental wirausaha mahasiswa diharapkan dapat mendorong jiwa mahasiswa untuk lebih memilih berwirausaha sebagai profesinya dalam menunjang kebutuhan ekonomi pribadinya maupun masyarakat sekitarnya. Tujuan penelitian ini untuk memperoleh gambaran tentang karakteristik sikap mental wirausaha pada mahasiswa DPTM FPTK UPI Bandung dalam bidang otomotif.

Wirausaha adalah seseorang yang siap menanggung ketidakpastian untuk terlibat dalam arbitrase beresiko, arbitrase yaitu membeli barang dan jasa dengan harga tertentu

\footnotetext{
${ }^{1}$ Mahasiswa Departemen Pendidikan Teknik Mesin FPTK UPI

${ }^{2}$ Dosen Departemen Pendidikan Teknik Mesin FPTK UPI

${ }^{3}$ Dosen Departemen Pendidikan Teknik Mesin FPTK UPI
} 
(tetap) di suatu pasar, supaya dapat dijualnya di tempat lain atau di lain waktu, untuk harga yang tidak pasti di masa depan. Pembentukan karakter wirausaha dapat dibina dengan berbagai cara. Melalui pengalaman hidup seseorang juga dapat secara alami membentuk karakternya sendiri untuk menjadi pribadi yang lebih baik. Selain pengalaman hidup, pendidikan juga membantu dalam pembinaan karakter wirausaha. Karakteristik kewirausahaan diantaranya: motivasi berprestasi, orientasi ke depan, menghadapi perubahan, kepemimpinan dan jaringan usaha (Kartib dan Yuyus, 2010).

Membangun karakter adalah proses membentuk kebiasaan atau pola pikir seseorang sedemikian rupa sehingga berbentuk unik, menarik, dan berbeda atau dapat dibedakan dengan orang lain. Pentingnya karakter dalam kewirausahaan yaitu bahwa karakter harus menjadi fondasi bagi kecerdasan dan pengetahuan (brains and learning) seorang wirausaha. Sikap adalah organisasi yang relatif abadi dari sebuah keyakinan, perasaan, dan kecenderungan prilaku terhadap sosial yang signifikan secara objek, kelompok, peristiwa, atau simbol. Tiga komponen sikap yang saling menunjang, yaitu: komponen kognitif merupakan representasi apa yang dipercayai oleh individu pemilik sikap, komponen afektif merupakan perasaan yang menyangkut aspek emosional, dan komponen konatif merupakan aspek kecenderungan berperilaku tertentu sesuai dengan sikap yang dimiliki oleh seseorang (Azwar, 1997).

Ketiga komponen yang diuraikan di atas merupakan komponen yang saling berhubungan antara satu dengan yang lainnya, artinya ketiga komponen tersebut secara bersama mengorganisasikan sikap individu. Teori mengatakan bahwa apabila salah satu saja diantara ketiga komponen sikap tidak konsisten dengan yang lain, maka akan terjadi ketidakselarasan yang menyebabkan timbulnya mekanisme perubahan sikap sedemikian rupa sehingga konsistensi itu tercapai kembali.

Mental adalah hal-hal yang berkaitan dengan psycho atau kejiwaan yang dapat mempengaruhi perilaku individu. Setiap perilaku dan ekspresi gerak-gerik individu merupakan dorongan dan cerminan dari kondisi (suasana) mental (Abbas, 2014). Sikap mental wirausaha berarti kecenderungan pribadi/jiwa seseorang yang membuahkan tindakan/tingkah laku, baik sebagai wirausaha atau potensi menjadi wirausaha. Kekuatan mental yang membangun kepribadian yang kuat ada enam (Ashidiq, 2013), diantaranya: berkemauan keras, berkeyakinan kuat atas kekuatan pribadi, yang diperlukan adalah pengenalan diri, kepercayaan pada diri sendiri, pemahaman tujuan dan kebutuhan, kejujuran dan tanggung jawab, yang diperlukan adalah moral yang tinggi dan disiplin diri sendiri, ketahanan fisik dan mental, yang diperlukan adalah kesehatan jasmani dan rohani, 
kesabaran, serta ketabahan, ketekunan dan keuletan untuk bekerja keras, dan pemikiran yang konstruktif dan kreatif.

\section{METODE PENELITIAN}

Metode penelitian yang digunakan pada penelitian ini adalah metode deskriptif dengan pendekatan kuantitatif. Melalui metode penelitian deskriptif dapat diperoleh deskripsi mengenai karakteristik sikap mental wirausaha mahasiswa. Teknik penentuan sampel yang dilakukan dalam penelitian ini menggunakan teknik Random Proportional Sampling, yaitu metode pengambilan sampel yang tiap unsur pembentuk populasi diberi kesempatan yang sama terpilih menjadi sampel. Adapun untuk menentukan jumlah sampel, maka digunakan rumus Slovin. Sampel dalam penelitian ini adalah mahasiswa FPTK UPI Bandung, Departemen Pendidikan Teknik Mesin, Prodi Otomotif, Jenjang Pendidikan S1, mulai angkatan 2010 sampai dengan 2013. Instrumen penelitian yang digunakan untuk mencari data variabel adalah angket.

\section{HASIL PENELITIAN}

Proses pencarian data mengenai sikap mental wirausaha dalam bidang otomotif, peneliti menggunakan angket sikap mental wirausaha yang terdiri dari 44 item pernyataan kepada 64 mahasiswa DPTM FPTK UPI Bandung, prodi otomotif, instrumen dibagikan kepada responden yang telah ditentukan dalam pengambilan sampel. Hasil penelitian terhadap sikap mental wirausaha dalam bidang otomotif mahasiswa DPTM FPTK UPI Bandung, dilihat dari rentang skor yang telah diklasifikasikan dan diinterpretasikan.

Tabel 1. Data sikap mental wirausaha mahasiswa

\begin{tabular}{cccc}
\hline Rentang Skor & Kategori & Frekuensi & Prosentase (\%) \\
\hline $127-140$ & Sangat Rendah & 9 & $14 \%$ \\
$140,5-149$ & Rendah & 10 & $15,5 \%$ \\
$149,5-158$ & Sedang & 16 & $25 \%$ \\
$158,5-167$ & Tinggi & 19 & $30 \%$ \\
$167,5-181$ & Sangat Tinggi & 10 & $15,5 \%$ \\
& & 64 & $100 \%$ \\
\hline
\end{tabular}

Skor rata-rata ideal sikap mental wirausaha mahasiswa dalam bidang otomotif yaitu sebesar 154. Sebanyak 50\% mahasiswa tergolong ke dalam kategori memiliki sikap mental wirausaha tinggi. Hal tersebut menunjukkan bahwa mayoritas mahasiswa DPTM FPTK UPI Bandung memiliki sikap mental yang tinggi untuk menjadi wirausaha dalam bidang 
otomotif. Interpretasi prosentase dari data hasil perolehan skor dari masing-masing responden adalah sebagai berikut:

Tabel 2. Koefisien mental wirausaha

\begin{tabular}{cccc}
\hline Interval Koefisien & Frekuensi & Prosentase $(\%)$ & $\begin{array}{c}\text { Tingkat } \\
\text { Kecenderungan }\end{array}$ \\
\hline $100 \%-81 \%$ & 2 & $3 \%$ & Sangat tinggi \\
$80 \%-61 \%$ & 61 & $95 \%$ & Tinggi \\
$60 \%-41 \%$ & 1 & $2 \%$ & Sedang \\
$40 \%-21 \%$ & 0 & $0 \%$ & Rendah \\
$20 \%-0 \%$ & 0 & $0 \%$ & Sangat rendah \\
Jumlah & 64 & $100 \%$ & \\
\hline
\end{tabular}

Data yang diperoleh menunjukkan bahwa 61 orang dari 64 mahasiswa DPTM FPTK UPI Bandung prodi otomotif memiliki tingkat kecenderungan memiliki sikap mental wirausaha tinggi (Tabel 2). Hampir seluruh responden memiliki sikap mental yang tinggi untuk menjadi wirausaha, hampir semua mahasiswa memiliki skor di atas skor rata-rata ideal. Data skor yang diperoleh ternyata lebih besar lagi jumlah mahasiswa yang memiliki sikap mental wirausaha yang tinggi. Semua mahasiswa memenuhi kategori di atas ratarata.

\section{PEMBAHASAN}

Penelitian dilakukan pada mahasiswa DPTM FPTK UPI Bandung prodi otomotif mulai angkatan 2010 sampai dengan angkatan 2013, dimana jumlah responden sebanyak 64 mahasiswa. Pembahasan hasil penelitian ini dimaksudkan untuk memberikan gambaran dan pemahaman dari hasil yang diperoleh dalam penelitian. Jumlah item soal sebanyak 44 item variabel sikap mental wirausaha dalam bidang otomotif.

Hasil yang diperoleh dari penelitian menunjukkan bahwa sikap mental wirausaha yang merupakan modal untuk menjadi wirausaha khususnya dalam bidang otomotif di kalangan mahasiswa prodi otomotif DPTM FPTK UPI Bandung, dilihat dari rentan skor, 9 mahasiswa (14\%) dari 64 (100\%) mahasiswa termasuk kedalam kategori yang memiliki sikap mental wirausaha yang sangat rendah, 10 mahasiswa (15,5\%) termasuk kedalam kategori yang memiliki sikap mental wirausaha yang rendah, 16 mahasiswa (25\%) termasuk kedalam kategori yang memiliki sikap mental wirausaha yang sedang, 19 mahasiswa (30\%) termasuk kedalam kategori yang memiliki sikap mental wirausaha yang tinggi dan 10 mahasiswa $(15,5 \%)$ termasuk kedalam kategori yang memiliki sikap mental wirausaha yang sangat tinggi. 
Lain lagi apabila dilihat dari interval koefisien skor tiap responden, 61 mahasiswa (95\%) memiliki hasil yang tinggi, 1 mahasiswa memiliki hasil sedang dan 2 orang mahasiswa memiliki hasil yang sangat tinggi. Semua mahasiswa memiliki potensi sikap mental wirausaha di atas rata-rata. Data tersebut merupakan temuan yang menunjukkan gambaran atau tingkatan sikap mental wirausaha dalam bidang otomotif di kalangan mahasiswa prodi otomotif DPTM FPTK UPI Bandung. Hal tersebut berarti bahwa mayoritas dari 64 mahasiswa sebagai sampel, memiliki sikap mental wirausaha yang tinggi khususnya dalam bidang otomotif.

Definisi sikap mental wirausaha secara gabungan ketiga kata tersebut, penulis sama sekali belum menemukannya, apabila secara operasionalnya banyak para ahli yang mendefinisikan sikap dan wirausaha sedangkan untuk mental sangat sedikit. Sebagian penulis di dalam blognya mengungkapkan bahwa definisi dari mental belum ada yang pasti. Sikap adalah organisasi yang relatif abadi meliputi keyakinan, perasaan, dan kecenderungan perilaku sosial secara signifikan terhadap objek, kelompok, peristiwa, atau symbol (Adopted Open Textbook, 2011). Sikap adalah suatu reaksi evaluasi atau reaksi perasaan. Perasaan seseorang terhadap suatu obyek adalah perasaan mendukung atau memihak (favorable) maupun perasaan tidak mendukung atau tidak memihak (unfavorable) pada obyek tersebut (Berkowitz,1972). Sikap sebagai derajat aspek positif dan aspek negatif terhadap suatu obyek psikologis (Thurstone, 1931). Obyek psikologis yang dimaksud adalah lambang-lambang, kalimat, semboyan, orang, institusi, profesi, dan ide-ide yang dapat dibedakan ke dalam perasaan positif atau negatif. Jelaslah bahwa sikap lebih cenderung kepada aksi atau tingkah laku manusia.

Mental yang penulis kutip dari blog definisinya yaitu hal-hal yang berkaitan dengan psycho atau kejiwaan yang dapat mempengaruhi perilaku individu. Setiap perilaku dan ekspresi gerak-gerik individu merupakan dorongan dan cerminan dari kondisi (suasana) mental. Beberapa ahli sama dalam mengungkapkan mental. Mental lebih cenderung kepada jiwa atau apa yang ada di dalam diri seseorang yang akhirnya akan berpengaruh pada aksi atau tingkah laku manusia. Mental terbagi 2, mental yang sehat dan mental yang tidak sehat. Pembahasan ini tentu lebih mengacu pada mental yang sehat karena secara realita semua responden memiliki mental yang sehat.

Kesehatan mental adalah keadaan kesejahteraan dimana individu menyadari kemampuan sendiri, dapat mengatasi tekanan normal kehidupan, dapat bekerja secara produktif dan baik. Mampu memberikan kontribusi kepada masyarakat sekitarnya. Wirausaha memiliki banyak definisi dari banyak para ahli (Sarvesh, 2012). 
Wirausaha adalah seseorang yang siap menanggung ketidakpastian untuk terlibat dalam arbitrase beresiko, arbitrase yaitu membeli barang dan jasa dengan harga tertentu (tetap) di suatu pasar, supaya dapat dijualnya di tempat lain atau di lain waktu, untuk harga yang tidak pasti di masa depan. Banyak sekali pendapat mengenai definisi kewirausahaan. Sikap mental wirausaha berarti kecenderungan pribadi atau jiwa seseorang atau individu yang membuahkan tindakan atau tingkah laku, baik sebagai wirausaha atau berpotensi menjadi wirausaha.

Prosentase hasil pengelompokkan dari masing-masing indikator sikap mental wirausaha, antara instrumen yang memiliki pernyataan positif dan negatif, semua pernyataan positif memiliki prosentase lebih besar dari pernyataan negatif. Kecenderungan mahasiswa memiliki sikap mental yang tinggi dan sehat dapat berpotensi menjadikannya wirausaha. Hal tersebut dikarenakan hasil penelitian membuktikan bahwa semua mahasiswa DPTM FPTK UPI Bandung yang dijadikan sampel memiliki nilai pada indikator sikap mental wirausaha diatas rata-rata.

Hasil penelitian membuktikan bahwa semua mahasiswa DPTM FPTK UPI Bandung yang dijadikan sampel memiliki nilai pada indikator sikap mental wirausaha diatas rata-rata. Walaupun pada kenyataannya, ada mahasiswa dari masing-masing kategori selain daripada kategori tinggi tersebut. Semua mahasiswa memiliki nilai dari masing-masing indikator diatas rata-rata sehingga pada prosentase interval koefisien mayoritas mahasiswa memiliki sikap mental wirausaha tinggi pula. Tingginya sikap mental wirausaha ini mengacu pada aspek sikap yaitu kognitif, afektif dan konatif yang dipadankan dengan indikator mental yakni berkemauan keras, berkeyakinan kuat atas kekuatan pribadi, kejujuran dan tanggung jawab, ketahanan fisik dan mental, ketekunan dan keuletan untuk bekerja keras, pemikiran yang konstruktif dan kreatif.

\section{KESIMPULAN}

Kesimpulan penelitian ini yaitu sikap mental wirausaha khususnya dalam bidang otomotif di kalangan mahasiswa prodi otomotif mayoritas memiliki sikap mental wirausaha pada kategori tinggi. Ada mahasiswa dari masing-masing kategori selain daripada kategori tinggi tersebut. Semua mahasiswa memiliki nilai dari masing-masing indikator diatas rata-rata sehingga pada prosentase interval koefisien mayoritas mahasiswa memiliki sikap mental wirausaha tinggi pula. Tingginya sikap mental wirausaha ini mengacu pada aspek sikap yaitu kognitif, afektif dan konatif yang dipadankan dengan indikator mental yakni berkemauan keras, berkeyakinan kuat atas kekuatan pribadi, 
kejujuran dan tanggung jawab, ketahanan fisik dan mental, ketekunan dan keuletan untuk bekerja keras, pemikiran yang konstruktif dan kreatif.

\section{DAFTAR PUSTAKA}

Abbas, H. (2014). Pengertian Mental. [Online] Tersedia: http://hakamabbas. blogspot.com/2014/01/pengertian-mental.html [27 Mei 2015]

Adopted Open Textbook. (2011). Entrepreneurial Behavior: Transforming and Innovative Idea into an Entrepreneurial Product. United Kingdom: Textbook Equiti, Inc.

Ashidiq, K. (2013). Materi Kewirausahaan. [Online] Tersedia: http://kholiqashidiq.blogspot.com/2013/06/materi-kewirausahaan.html [27 Mei 2015]

Azwar, S. (1997). Sikap Manusia Teori dan Pengukurannya. Yogyakarta: Pustaka Pelajar.

Berkowitz, L. (1972). Social Psychology Glenview Scot Fosesman and company. New York: Logman.

Hogg, M.A. dan Vaughan, G.M. (2005). Introduction to Social Psychology [4th Ed.]. Australia: Pearson Prentice Hall.

Kartib dan Yuyus. (2010). Kewirausahaan Pendekatan Karakteristik Wirausahawan Sukses. Jakarta: Kencana Predana Media Group.

Sarvesh, S. (2012). Mental Health Perspectives In Organizations: Issues And Challenges. Rajasthan: International Jurnal of Research Commerce, IT \& Management.

Thurstone, L. L. (1931). The Measurement of Attitudes. New York: Journal of Abnormal and Social Psychology. 